\title{
AKAR TERORISME DALAM ISLAM?
}

\author{
Sukendar \\ Dosen Fakultas Ushuluddin IAIN Walisongo \\ Jl. Prof. Dr. Hamka Km.1, Ngaliyan, Semarang \\ e-mail:sukendar@yahoo.com
}

\begin{abstract}
Terrorism has been a popular issue since September the Eleven. The incident was followed by a proclamation of war against terrorism by the US governments. The US invited other countries to join the campaign with President George W. Bush's monumental saying "You are either with us, or against us". The effort of countering terrorism by the US and other countries with weapon is likely to be ineffective. Countering terrorism, especially religious motivated terrorism, can effectively be conducted by understanding the root causes of terrorism and eliminating what so-called global injustice.
\end{abstract}

Abstrak: Terorisme menjadi isu populer sejak 11 September (2001). Insiden ini diikuti dengan sebuah proklamasi perang melawan terorisme oleh pemerintah USA. USA mengajak negara-negara lain untuk bergabung kampanye dengan perkataan monumental Presiden George W. Bush, "Anda bersama kami, atau melawan kami." Usaha menghadapi terorisme oleh USA dan negara-negara lain dengan senjata tampaknya tidak efektif. Melawan terorisme, khususnya terorisme yang dimotivasi oleh agama, bisa efektif dilakukan dengan memahami akar penyebab terorisme dan mengeliminasi apa yang disebut ketidakadilan global

Keywords: terorisme, Islam, ideologi, counter terrorism

\section{A. Pendahuluan}

Sejarah munculnya istilah terorisme menurut Fred Halliday terjadi saat Revolusi Perancis. Saat itu pengertian istilah terorisme dilekatkan kepada terror yang dilakukan oleh negara terhadap rakyatnya. Namun saat ini penggunaan istilah terorisme lekat pada pengertian penggunaan kekerasan yang dilakukan oleh rakyat kepada Negara atau rakyat yang lain. ${ }^{1}$ Sejalan dengan perkembangan sejarah, dan aktivitas terorisme yang semakin marak dengan modus yang semakin bervariasi, 
maka definisi terorisme pun berkembang. Terdapat tidak kurang dari serat us definisi terorisme yang ada dalam studi terorisme. ${ }^{2}$

Menurut the Oxford dictionary, sebagaimana dikutip oleh Campbell, teroris adalah "a person who uses violence and intimidation in the pursuit of political aims," ${ }^{3}$ yaitu, seseorang yang menggunakan cara-cara kekerasan dan intimidasi untuk mencapai tujuan-tujuan politiknya. Ekaterina Stepanova, seorang ahli terrorism dari SIPRI (Stockholm International Peace Research Istitute), memiliki definisi yang tidak jauh dari Oxford Dictionary di atas, yaitu "Terrorism is intentional use of threat or violence by non-state actors against civilian/non-combatants to apply pressure on state and intimidate the society, in order to achieve political goals". ${ }^{4}$ Pada tahun 2004, laporan dari Sekretaris Jendral Persatuan Bangsa Bangsa (PBB), mendeskripsikan terorisme sebagai "any act intended to cause death or serious bodily harm to civilians or non-combatants with the purpose of intimidating a population or compelling a government or an international organization to do or abstain from doing any act". ${ }^{5}$

Meskipun telah banyak upaya mendefinisikan terorisme, namun menurut Halliday, istilah terorisme tetap saja "one of the most confusing and contested words in the political lexicon". ${ }^{6}$ Banyak para sarjana atau politikus yang berusaha untuk berbicara tentang terorisme, namun semuanya selalu berakhir pada pertentangan masalah definisi, yaitu mendefinisikan dan membedakan antara terorisme dengan aktivitas kriminal atau tindakan militer.

Sulitnya mendefinisikan terorisme dikarenakan oleh fakta bahwa kata terorisme ini adalah sebuah labeling (penjulukan). Disebut labeling karena kata ini hampir tidak pernah bisa diterima oleh mereka, baik individu maupun kelompok, yang disebut teroris. Usamah bin Laden dan pelaku bom Bali, misalnya, mereka tidak pernah menyebut dirinya sebagai teroris, tetapi menyebut diri mereka para pejuang Islam yang menentang penindasan Barat khususnya Amerika Serikat. Fauzan alAnshari, seorang tokoh Majelis Mujahidin Indonesia (MMI), dalam sebuah diskusi tentang Bom Bali mengatakan,

"Jadi memang selama ini terorisme selalu tidak terdefinisikan. Akhirnya terjadi standar ganda...Sekarang Indonesia telah masuk perangkap kampanye isu anti terorisme yang dilansir oleh Amerika. Kemudian kenapa sasaran dari terorisme itu adalah Islam fundamentalis?... [Ame- 
rika] menulis ada lima ciri Islam fundamentalis. Pertama, mereka yang anti pada Barat. Kedua, mereka yang ingin menerapkan Syariat Islam. Ketiga, mereka yang ingin membangun peradaban Islam. Keempat, mereka yang tidak ingin memisahkan Islam dan negara. Dan kelima, mereka yang menjadikan masa lalu menjadi panduan untuk masa depan. Sehingga dengan ciri lima ini mana pun dan di mana pun gerakan Islam, maka akan dicap sebagai gerakan Islam fundamentalis sama dengan teroris."

Label teroris ini hampir selalu digunakan oleh pemerintah yang diserang oleh mereka yang disebut 'teroris'. Pemerintah Amerika, misalnya, mendefiniskan terorisme sebagai 'the calculated use or threat of violence to inculcate fear, intended to coerce or intimidate governments or societies'. Pemerintah Inggris mendefinisikan terorisme sebagai, 'the use or threat, for the purpose of advancing a political, religious, or ideological course of action, of serious violence against any person or property'.

Selain karena factor labeling, kesulitan mendefinisikan terorisme juga dikarenakan seseorang yang dianggap teroris bagi sebagian orang, bisa juga dianggap sebagai pejuang kebebasan (freedom fighter) bagi sebagian yang lain. Sebagai contoh, dalam sejarah perjuangan Indonesia, Pangeran Diponegoro, misalnya, dianggap teroris oleh pemerintah Hindia Belanda yang harus ditumpas. Namun, bagi rakyatnya, Diponegoro adalah pejuang pembebasan, dan pada akhirnya dinobatkan menjadi pahlawan nasional bangsa Indonesia.

Senada dengan hal di atas, Abu Bakar Ba'asyir, mantan Amir MMI yang juga pengasuh Pondok Pesantren al-Mukmin Ngruki mengatakan,

Masalah teror mari kita jangan menutup mata dan telinga. Istilah teror ini dimonopoli definisinya oleh Amerika dan itu diarahkan teror itu kepada orang Islam...Itulah pengertian teroris yang dimonopoli oleh orang Amerika. Ini satu kenyataan. Kalau kita kembali kepada definisi teror yang sebenarnya itu harus berdasarkan kenyataan suatu perbuatan yang merusak dan menakut-nakuti orang. Kalau kita melihat apa alasan Amerika mengebom Afganistan. Apa alasan Amerika mengejar-ngejar Osama dengan tuduhan terlibat mengebom WTC. Tetapi pada sampai akhirnya Amerika tidak bisa membuktikan. Itulah teror yang sebenarnya. Sekarang Israel membunuh bangsa Palestina, menjajah bangsa Palestina. Dengan enak membunuhi anak-anak, perempuan, 
rumah-rumah dihancurkan dengan begitu enak, dan itu dibantu oleh Amerika. Itulah arti teror yang sebenarnya. ${ }^{9}$

\section{B. Islam dan Terorisme}

Beberapa kalangan menganggap peristiwa 11 September $2001^{10}$ sebagai sebuah starting point dari sebuah fase khusus sikap masyarakat Barat, khususnya Amerika Serikat terhadap umat Islam. Masyarakat Amerika mulai melihat orang-orang Islam dengan identitas khusus. Peristiwa 11 September atau yang sering ditulis media massa Amerika 9/11 (September the eleven) memakan korban sekitar tiga ribu warga Amerika. Peristiwa inilah yang membuat Presiden George W. Bush menyerukan perang terhadap terorisme dengan slogannya yang terkenal yang ditujukan kepada negara-negara lain, "you are with us or against $u s "$ ("kalian berperang bersama kami atau melawan kami"). ${ }^{11}$

Umat Islam menduga kuat bahwa yang dimaksud Bush dengan perang melawan teroris adalah perang melawan umat Islam atau negaranegara Islam. Hal ini dikarenakan Bush menyatakan bahwa pengeboman yang dilakukan oleh para "teroris muslim" adalah bentuk kebencian mereka terhadap Amerika Serikat. Secara eksplisit Bush menyatakan, "They hate our freedom of religion, our freedom of speech, our freedom to vote and assemble and disagree with each other."12 Bahkan sempat terlontar dari mulut Bush bahwa peperangan melawan teroris ini bernuansa agama sama seperti perang salib. Kenyataan bahwa yang dijadikan target serang dalam penumpasan terorisme adalah negara-negara Islam seperti Irak dan Afghanistan, dan menyusul kemudian tuduhannya kepada Iran dan Syria yang ia sebut sebagai pendukung terorisme, semakin memperkuat dugaan umat Islam di dunia bahwa yang dimaksud teroris adalah umat Islam.

Meskipun Bush, karena berbagai tekanan, telah melunakkan sikapnya terhadap umat Islam $^{13}$, dan dalam beberapa kesempatan mengoreksi pernyataan awalnya dengan mengatakan bahwa perang yang dilancarkan oleh pemerintahannya terhadap terorisme bukanlah perang terhadap Islam. ${ }^{14}$ Namun tidak seluruh umat Islam dengan serta merta memercayainya. Hal ini dikarenakan umat Islam melihat, termasuk Muslim Amerika, bahwa diskursus mengenai Islam dan terorisme yang dikembangkan pemerintah Amerika telah berdampak pada kehidupan umat Islam di dunia, dan lebih khusus di Amerika.

TEOLOGIA, Volume 23, NOMOR 2, Juli-DeSEMBER 2012 
Sebuah organisasi masyarakat Islam di Amerika, Council on American-Islamic Relations (CAIR), menyatakan bahwa setelah insiden 11 September 2001 telah terjadi beberapa tindakan yang bernuansa balas dendam terhadap bebarapa masjid dan komunitas Muslim di Amerika Serikat. CAIR melaporkan:

"Not only did Muslims die in the attacks, but they also had to cope immediately with a violent backlash and lingering anti-Muslim agitation. Islamaphobes came out strongly in favor of placing the guilt on the religion of Islam and the worldwide community of Muslims."

Media masa terkenal di Amerika Serikat Newsweek pada edisi 15 Oktober 2001 dengan sangat jelas memberikan judul pada sampulnya "Why They Hate Us: The Roots of Islamic Rage and What We Can Do About It" (Mengapa mereka membenci kita: Akar-akar kemarahan Islam dan apa yang bisa kita lakukan tentangnya). ${ }^{16}$ Ini menunjukkan bahwa mereka merasa dijadikan obyek kebencian oleh umat Islam. Bahkan Samuel Harris, pengarang buku The End of Faith, menyatakan dalam the Washington Times, pada edisi tahun 2004: "It is time we admitted that we are not at war with terrorism. We are at war with Islam." ${ }^{17}$ Sebuah gereja di Idaho, mensejajarkan Islam dengan kejahatan. Di depan gereja tersebut terpampang sebuah banner dengan tulisan "The spirit of Islam is the spirit of the Antichrist." 18

Dalam kurun waktu enam bulan pertama pasca serangan 11 September, CAIR mendapatkan laporan adanya 1717 serangan, tindak kekerasan dan tindakan diskriminatif terhadap muslim di Amerika. ${ }^{19}$

Dari sisi psikologis, umat Islam di Amerika, terutama imigran asal Timur Tengah, mengalami kondisi yang sangat berat karena terus dicurigai, diteror, diserang, dilecehkan dan diasosiasikan dengan teroris. ${ }^{20}$ Pemerintah George Bush mengetatkan aturan imigrasi dan mengawasi kaum imigran Muslim secara berlebihan. Siaran televisi Fox News Channel, dalam acara mingguan "In Focus" menggelar diskusi dengan mengundang enam orang nara sumber, bertemakan "Stop All Muslim Immigration to Protect America and Economy." Acara ini menggambarkan kekhawatiran Amerika tidak hanya dalam masalah terorisme tetapi juga ekonomi dimana pengaruh para pengusaha Arab dan Timur Tengah mulai dominan dan mengendalikan ekonomi Amerika. ${ }^{21}$ 
Salah satu dampak pasca serangan 11 September yang juga dirasakan umat Islam dan warga Amerika keturunan Arab di Amerika adalah meningkatnya apa yang disebut Profiling. Pengertian profiling adalah tindakan untuk mencurigai seseorang hanya karena etnisitas atau rasnya. Profiling menjadi perhatian besar Hussein Ibish, Direktur Komunikasi Komite Anti Diskriminasi Warga Amerika Keturunan Arab, atau disingkat ADC. Selama dua dasawarsa ini, ADC yang berkantor pusat di Washington memantau status hak sipil warga Amerika keturunan Arab. Ibish mengatakan bahkan sebelum serangan 11 September, profiling terhadap warga Amerika keturunan Arab, biasa dilakukan oleh pemerintah Amerika terutama di airport-airport. Ibish mengatakan,

"Meskipun kebijakan resmi mengatakan orang tidak boleh dicurigai hanya karena etnisitas dan ras mereka, tetapi kenyataannya para penguasa itu menyatakan secara terbuka kepada para wartawan dan lainnya bahwa melakukan profiling. Ribuan warga Amerika keturunan Arab menjadi sasaran hanya karena etnisitas dan ras mereka." ${ }^{22}$

Hassan Jabir, Wakil Direktur organisasi bernama ACCESS, sebuah organisasi sosial yang melayani masyarakat Amerika keturunan Arab di Dearbon, Michigan, mengatakan bahwa masyarakat Amerika keturunan Arab merasa menjadi sasaran karena etnisitas mereka. Padahal mereka tidak mempunyai sangkut paut dengan serangan teroris itu, bahkan mereka pun merasakan hal yang sama seperti yang dirasakan oleh warga Amerika lainnya. ${ }^{23}$

Selain profilling, hal lain yang harus ditanggung sebagai beban umat Islam di Amerika adalah apa yang disebut dengan labelling. Pemerintah Amerika menuduh Usamah Bin Laden sebagai orang yang paling bertanggungjawab atas terjadinya teror tersebut. Namun, yang susah untuk dimengerti umat Islam, tuduhan tersbut juga diiringi dengan label Islamic Terrorism, Islamic Fundamentalism, dan lain-lain. Efeknya, berbagai media massa di AS seakan digiring untuk membahas issue Islam dan kekerasan. Akibatnya, menjamurlah insiden kekerasan terhadap muslim dan muslimah di Amerika. ${ }^{24}$

Pelabelan ini, menurut Anies Baswedan, terasa ganjil dan mengganggu, karena ketika terjadi berbagai pengeboman klinik aborsi di AS oleh penganut Kristen, yang melakukan pemboman itu atas nama 
agamanya, para oknum itu disebut anti-abortion extremist bukan Christian terrorist. Atau ketika puluhan umat Islam yang sedang bersholat Shubuh di Masjid Ibrahim di Hebron mati ditembaki dengan senjata otomatis oleh seorang dokter Yahudi, lalu label yang diberikan adalah Anti-Arab Militant, bukan Jews terrorist. Demikian pula ketika Ku Klux Klan membantai warga berkulit hitam, mereka disebut Racist bukan Christian Terrorist meski mereka selalu membawa simbol-simbol Christianity dalam ritual dan memotivasi gerakannya. Tapi, ketika rakyat palestina menyatakan perlawanan terhadap pendudukan Israel, mereka disebut Teroris, bukan Anti-Zionist Israel atau ketika Al-Qaidah menyatakan perang dan menyerang Amerika, mereka disebut Islamic Terorrist atau Islamic fundamentalist bukan Anti-America. ${ }^{25}$

\section{Akar Terorisme}

Stepanova, dalam sebuah kuliah tentang terorisme di European University Centre for Peace Studies (EPU) Austria, di Fall Trimester 2009 , mengatakan bahwa saat ini trend terorisme memang didominasi oleh apa yang ia sebut religious group yang menggantikan nationalist and left wing terrorism. Wacana saat ini menunjukan bahwa religious groups ini didominasi oleh apa yang ia sebut sebagai Islamist terrorism.

Kegiatan terorisme yang dilakukan sebagian masyarakat Islam tentulah memiliki sebab. Tindakan kekerasan selalu memiliki justifikasi. Menurut David Apter, jika terorisme dianggap sebagai tindakan yang bertujuan politis, maka kekerasan yang digunakan para teroris bisa disebut sebagai kekerasan politik. Ia menyatakan, "People do not commit political violence without discourse. They need to talk themselves into it. What may begin as casual conversation may suddenly take a serious turn. Secret meetings add portent. On public platforms it becomes inflammatory. It results in texts, lectures. In short it engages people who suddenly are called upon to use their intelligence. Political violence then is not only interpretive, it engages the intelligences in ways out of the ordinary. It takes people out of themselves" ${ }^{26}$

Islamist terrorism yang juga sering disebut dengan global terrorism atau super terrorism menurut Stepanova bertujuan untuk mengubah tata dunia. Tujuan tersebut adalah sebagai agenda yang tak 
terbatas, yang diperjuangkan dengan cara yang beragam macam. Menurut Stepanova, Islamist terrorist muncul akibat dari proses modernisasi yang sering juga disebut sebagai westernisasi. Perasaan terhina (humiliated), khususnya oleh konsep-konsep modernisasi yang merendahkan nilai-nilai ataupun tradisi yang dipegangi masyarakat Muslim, dan ketakutan akan kehilangan identitas adalah faktor yang sangat berpengaruh bagi sebagian umat Islam melakukan tindakan penentangan terhadap Barat, yang salah satunya mengambil bentuk terorisme.

Menurut Sabine Von Schorlemer, penyebab terorisme selalu berkaitan erat dengan pelanggaran hak asasi manusia. Komisi Persatuan Bangsa Bangsa (PBB) untuk urusan hak asasi manusia dalam laporannya tentang "Terrorism and Human Rights" menyatakan bahwa, "Violation of human rights, humanitarian law and basic principles of the (UN) Charter, are among the major causal factors of terrorism". ${ }^{27}$

Di Chechnya, misalnya, beberapa serangan teroris dilakukan dengan pemboman bunuh diri yang dilakukan oleh para perempuan yang sering disebut dengan "the Black Widows". Mereka melakukan bunuh diri sebagai upaya pembalasan terhadap kekejaman tentara Rusia yang membunuh suami atau saudara mereka. Mereka menyatakan bahwa apa yang mereka lakukan hanyalah mempertahankan hak-hak mereka.

Demikian pula dalam kasus peperangan di Irak dan Afghanistan. Photo-photo yang berisi tentang penyiksaan ataupun korban serangan Amerika dari warga Iraq dan Afghanistan telah tersebar, dan dengan mudah bisa didapat oleh umat Islam di seluruh dunia melalui media internet. Bagi sebagian umat Islam, photo-photo tersebut bisa mereka jadikan bukti kekejaman maupun penghinaan dan pelanggaran hak-hak asasi manusia terhadap sesama muslim. Hal tersebut bisa memunculkan radikalisasi umat Islam di berbagai negara. Ini bisa jadi menjawab pertanyaan kenapa Taliban tidak mudah untuk dikalahkan. Bisa jadi karena mereka mendapat dukungan dari beberapa umat Islam di berbagai dunia. Terdapat dugaan bahwa pasukan Amerika Serikat dan sekutunya yang berada di Afghanistan tidak hanya bertempur melawan Taliban dari Afghanistan dan Pakistan, namun juga melawan Taliban multinasional, entah dari Chechya, Rusia, Arab Saudi, Malaysia, Thailand atau Indonesia. Dari sisi latar belakang negara mereka, bisa jadi pasukan Amerika dengan negara-negara yang tergabung dalam

TEOLOGIA, Volume 23, NOMOR 2, Juli-DeSEMBER 2012 419 
ISAF (International Security Assistance Force), bisa jadi menghadapi jumlah negara yang sama atau bahkan lebih banyak. Sehingga yang terjadi adalah peperangan pasukan multinasional pimpinan Amerika melawan pasukan multinasional pimpinan Taliban. Masuknya para Taliban multinasional secara ilegal ke dalam Afghanistan untuk bergabung dengan Taliban adalah hal yang sangat memungkinkan. Hal ini mengingat Afghanistan memiliki kesulitan dalam mengelola perbatasannya dengan negara-negara lain, khususnya Pakistan.

Perasaan terhina (feeling of being humiliated), sebagai factor penting sebab munculnya terorisme telah diteorikan oleh Evelyn Gerda Lindner. Tentang humiliation ini ia menyatakan, "Humiliation means the enforced lowering of a person or group, a process of subjugation that damages or strips away their pride, honour or dignity. To be humiliated is to be placed, against your will and often in a deeply hurtful way, in a situation that is greatly inferior to what you feel you should expect". ${ }^{28}$

Lindner menegaskan bahwa orang seperti Usamah bin Laden tidak akan pernah mendapat dukungan jika saja tidak ada tumpukan perasaan terhina dalam skala massif dan global. Inilah alasan yang bisa menjawab pertanyaan kenapa beberapa orang muda, pintar, kaya dan berpendidikan mau melakukan serangan terorisme dan bahkan serangan bunuh diri. "The rich and powerful West has long been blind to the fact that is superiority may have humiliating effects on those who are less privileged, especially during times when West simultaneously teaches the world the ideals of human rights". ${ }^{29}$

Pernyataan Linder di atas senada dengan Abu Bakar Baasyir, yang menyatakan bahwa Amerika telah melecehkan dan memerangi umat Islam. Di tambah lagi menurut Abu Bakar Ba'asyir, bahwa Amerika adalah pendukung setia Israel, sedangkan Israel adalah pembunuh bangsa Palestina, penjajah bangsa Palestina. "Dengan enak membunuhi anak-anak, perempuan, rumah-rumah dihancurkan dengan begitu enak, dan itu dibantu oleh Amerika. Itulah arti teror yang sebenarnya". ${ }^{30}$

Pernyataan Ba'asyir di atas, diamini Noor Huda Ismail, Direktur Eksekutif Yayasan Prasasti Perdamaian yang juga alumnus pesantren Ngruki. Noor Huda menyatakan bahwa di antara faktor yang menyumbang suburnya terorisme adalah ketidakadilan global (global 
injustice). Ia menceritakan bahwa Ali Imron dalam sebuah wawancara dengan seorang agen FBI yang menginterogasinya tentang bagaimana cara menghentikan aksi terror mengatakan "Kalau kalian tidak pernah mengubah sikap terhadap dunia Islam, kami para Mujahid tidak akan pernah berhenti menebar terror kepada kalian". ${ }^{31}$ Bagi orang seperti Ali Imron, pernyatan "global war on terror" yang diproklamirkan Bush layak dijawab dengan "global jihad against US and its interests".

Pernyataan di atas juga didukung oleh Usamah bin Laden, yang mengatakan bahwa pemboman yang dilakukan terhadap kepentingankepentingan Amerika adalah harga yang harus dibayar oleh Amerika atas ketidakadilan mereka terhadap dunia Islam. ${ }^{32}$

Uniknya, pernyataan Usamah di atas juga dikemukakan banyak kalangan diseluruh dunia yang menyatakan bahwa "America got what it deserved", ${ }^{33}$ Amerika mendapatkan apa yang layak ia dapatkan. Anies Baswedan menyatakan bahwa ketidaksukaan banyak orang dan banyak negara terhadap pemerintah Amerika dan kebijakannya adalah sebuah kenyataan yang harus dijadikan bahan introspeksi bagi bangsa Amerika. $^{34}$

Dari sisi teori hubungan antara Islam dengan Barat, maraknya terror khususnya peristiwa September the eleven ini, juga semakin memperkuat tesis Huntington tentang the clash of civilization (benturan antar peradaban), yaitu antara peradaban Islam dan Barat. Namun, tesis Huntington mengenai benturan peradaban Islam dan Barat di atas ditolak oleh Robert W Hefner, yang menyatakan, " There is no clash of civilizations between Islam and the West. The really decisive battle is taking place within Muslim civilization, where ultraconservatives compete against moderates and democrats for the soul of the Muslim public." 35 Bantahan senada juga dikemukakan oleh Akbar S. Ahmed, seorang professor International Relations, American University, Washington, D.C. ${ }^{36}$

\section{Ideologi "Islamists Terrorist"}

Noor Huda Ismail menggambarkan hasil liputannya pada saat pemakaman Amrozi dan Mukhlas di Lamongan. Ia menulis, 
Ketika meliput pemakaman Amrozi dan Mukhlas di Lamongan, saya menyaksikan antusiasme ribuan pendukung ideologi ini. Mereka berdatangan dari berbagai daerah di wilayah Jawa Tengah, Jawa Timur, bahkan Malaysia. Dalam waktu yang sangat singkat, mereka membuat media centre dengan banner besar bertuliskan Kafilah Syuhada, membuat dapur umum dan mengambil alih seluruh prosesi pemakaman ini. Jasad Amrozi dan Mukhlas disambut bak pahlawan dan itu menginspirasi banyak orang. ${ }^{37}$

Noor Huda mengatakan bahwa alasan hal tersebut di atas terjadi adalah karena masalah ideologi. Islamic terrorism adalah masalah ideologi. ${ }^{38}$ Menurut Stepanova, ideologi yang berada di balik Islam radikal dan Islamic terrorism adalah apa yang ia sebut dengan Islamism ideology. Ideologi ini bertujuan untuk menciptakan sebuah kekhalifahan global (global caliphate) dan mengganti tata dunia. Untuk mewujudkan tujaun ini, mayoritas pendukung ideology ini menggunakan cara-cara non-kekerasan sebagaimana yang dilakukan oleh Hizbut Tahrir. Meskipun demikian, menurutnya, ada sejumlah kecil umat Islam yang menggunakan kekerasan yang masuk dalam kategori tindak terorisme. ${ }^{39}$

Ideologi ini merupakan senjata ampuh bagi para teroris, sesuatu yang tidak dimiliki oleh orang Barat. Kekuatan dari apa yang disebut Islamist terrorist menurut Stepanova terletak pada ideologinya.

Ada beberapa ajaran yang menjadi basis ideologi gerakan jihad global ini. Pertama, adalah pesona syahid. Bagi penganut ideologi ini, pertama, prinsip utama yang harus dimiliki dalam hidup adalah "inna alhayāta là aqīdatun wa jihădun" (hidup adalah untuk mempertahankan akidah dan jihad), kedua, kemenangan atau kekalahan bukanlah tujuan utama, yang terpenting adalah adanya kegiatan untuk terus menerus memperjuangkan cita-cita, ketiga, kematian hanyalah untuk Allah, perjuangan mereka bukanlah bertujuan untuk hal-hal yang bersifat material. Sehingga ketika terbunuh pun mereka tidak membutuhkan upacara pemakaman ataupun bendera. Prinsipnya adalah "wa kafá bi Allāhi shahìda" (QS. al-Nisā' [4]: 79), keempat, mereka berpegang teguh pada prinsip "Ish kariman aw mut shahidan" (Hidup mulia atau mati syahid), yang menunjukan mereka tidak ingin dihina. Hal ini juga 
pernah diproklamasikan oleh para pejuang kemerdekaan Indonesia dengan slogannya "Merdeka atau mati", kelima, orang yang mati syahid tidaklah mati, tetapi hidup di hadapan Tuhannya. Untuk mendukung pernyataan ini, mereka kerap merujuk pada QS. Ali 'Imrān [3]: 169. ${ }^{40}$

\section{E. Bagaimana Meng-Counter Terorisme?}

Karena kegiatan terorisme melibatkan ideologi, maka usaha counter terrorism, menanggulangi terorisme tidaklah bisa dilakukan dengan senjata, atau hanya dilakukan oleh Densus 88 semata. Memerangi ideologi dengan senjata adalah hal yang perlu dipertanyakan efektifitasnya. Noor Huda mengusulkan kepada seluruh pihak yang berkepentingan untuk secara simultan melakukan proses deradikalisasi ideologi para teroris. Di samping itu, para eks-mujahid juga hendaknya dikelola dengan memikirkan kegiatan ekonomi mereka. Hal ini agar mereka memiliki pengalaman yang berbeda, tidak sebatas pengalaman bertempur sebagaimana yang mereka dapat di Afghanistan. ${ }^{41}$

Kegiatan lainnya adalah perlunya koreksi terhadap pemahaman mereka yang berjihad dengan kekerasan. Sebagaimana Abu Bakar Ba'asyir yang memberikan nasehat yang tertuang dalam buku Mengoreksi Jihad Global Imam Samudra. Sebagaimana dikutip Noor Huda, Abu Bakar Ba'asyir menyatakan, "Kenapa mereka mengebom di wilayah aman? Kalau di wilayah perang tidak apa-apa. Dalam wilayah perang saja, wanita dan anak-anak tidak boleh dibunuh atau dianiaya. Jadi, memang ada yang perlu dikoreksi dari langkah jihad mereka". ${ }^{42}$

Hal yang juga penting dilakukan adalah menghilangkan ketidakadilan global (global injustice), dengan menciptakan hubungan antar Negara yang adil dan seimbang. Di samping itu suporioritas ras maupun kesombongan ekonomi dan budaya haruslah dihilangkan karena hal tersebut bisa menyebabkah perasaan terhina yang akhirnya menimbulkan upaya-upaya pembalasan yang berefek negative. Negaranegara Barat, khususnya Amerika juga harus menghilangkan standar gandanya dalam konflik di Timur Tengah khususnya anatara Israel dan palestina. PBB, dalam hal ini Dewan Keamanan haruslah bisa memberikan perlindungan yang adil kepada semua anggotanya.

TEOLOGIA, Volume 23, NOMOR 2, Juli-DeSEMBER 2012 
Selain itu dukungan terhadap Islam moderat perlu diupayakan secara terus menerus. Orang non-Muslim harus mengetahui bahwa mayoritas umat Islam adalah umat moderat yang anti kekerasan. Dalam kasus 11 September, umat Islam moderat telah menyatakan kecamannya terhadap serangan 11 September, karena telah mengakibatkan melayangnya nyawa warga sipil yang tak bersalah. Esposito bahkan menambahkan bahwa kalangan muslim moderat banyak yang merujuk kepada ayat-ayat al-Qur'an untuk menyatakan ketidaksetujuan mereka terhadap tindakan terorisme. Mereka juga mengemukakan satu ayat yang mengatakan bahwa pembunuhan terhadap seorang manusia tanpa dosa sama dengan pembunuhan terhadap seluruh manusia. ${ }^{43}$ Hal ini dikuatkan pula oleh polling yang dilakukan oleh the Gallup Center for Muslim Studies yang menunjukan bahwa 90 persen umat Islam di dunia tidak mendukung terorisme. Selain itu, 93 persen dari total populasi 1,3 milyar di dunia adalah umat Islam moderat, hanya 7 persen saja yang secara politik radikal. Survey ini didasarkan pada jawaban 50.000 responden dari umat Islam di 40 negara baik Afrika, Asia, Eropa dan Timur Tengah. ${ }^{44}[]$

\section{Catatan Akhir:}

${ }^{1}$ Fred Haliday, 2004, Terrorism in historical perspective, h. 4-5, (online) available: http://www.opendemocracy.net/articles/ ViewPopUpArticle.jsp?id= 2\&articleId $=1865$ Terrorism).

${ }^{2}$ Wikipedia, Wikipedia, the free encyclopedia, (http://en.wikipedia.org/wiki/

${ }^{3}$ Campbell, David, 2004, Dad what's a terrorist?, h. 1, Available online: http://www.theage.com.au/articles/2004/04/22/1082616260498.html

${ }^{4}$ Ekaterina Stepanova, Terrorism in Asymmetrical Conflict Ideological and Structural Aspect, SIPRI Research Report No. 23, Oxford University Press, 2008, h. 5

${ }^{5}$ Wikipedia, Wikipedia, the free encyclopedia, (http://en.wikipedia.org/wiki/ Terrorism).

${ }^{6}$ Fred Halliday, Op. Cit, pp.1

${ }^{7}$ Abu Bakar Ba'asyir, transkrip diskusi bersama Diskusi Ulil Abshar-Abdalla dan Abu Bakar Ba'asyir dll, "Bom di Bali, Islam dan terorisme", disiarkan Radio 68H 
(Jakarta) dan jaringannya pada tanggal 22 November 2002. Artikel online: (http://media.isnet.org/islam/Etc/BomBali.html).

${ }^{8}$ Charles Townshend, 2002, Terrorism, A Very Short Introduction, Oxford University Press, New York, pp. 3-4.

${ }^{9}$ Abu Bakar Ba'asyir, transkrip diskusi bersama Diskusi Ulil Abshar-Abdalla dan Abu Bakar Ba'asyir dl.

${ }^{10}$ Yang dimaksud peristiwa 11 September 2001 atau yang sering disebut dengan 11/9 (September the eleven) adalah peristiwa pemboman terhadap gedung World Trade Center (WTC) dan beberapa tempat lain di Amerika Serikat dengan modus operandi pembajakan pesawat dan meledakannya pada target pemboman.

${ }^{11}$ Ehito Kimura, Indonesia and Islam: Before and After 9/11, Peace Work, December 2001/January 2002, hlm. 1, artikel online: http://www.peaceworkmagazine.org/pwork/0112/011216.htm

${ }^{12}$ Pipes, Daniel, A New Round of Anger and Humiliation: Islam After 9/11, Our Brave New World, 2002, hlm. 1, artikel online: http://www. danielpipes.org/417/a-newround-of-anger-and humiliation-islam-after-9-11

13 NewsVoaCom, Umat Islam di Amerika Setelah Serangan Teroris 11 September, 05/10/2001, artikel online: http://www.voanews.com/indonesian/ archive/2001-10/a-2001-10-05-5-1.cfm?renderforprint=1\&pageid=73725

${ }^{14}$ Bush menegaskan pesannya itu dengan secara simbolis mengunjungi Islamic Center di Washington. Di masjid agung itu Bush mengatakan: "Wajah teror bukanlah wajah Islam yang sejati. Itu bukanlah ajaran Islam. Islam adalah perdamaian. Teroristeroris ini tidak mewakili perdamaian, mereka mewakili kejahatan bahkan lebih buruk dari itu. Islam adalah agama yang memberikan kepuasan batin kepada milyaran manusia di dunia. Di Amerika sendiri banyak terdapat orang-orang Islam."

${ }^{15}$ Islam Online, Report: After 9/11 Muslims Witnessed The Good, Bad \& Ugly, h. 2, artikel online: http://www.islamonline.net/English/News/200209/07/article20.shtml

${ }^{16}$ Robert W. Hefner, September 11 and the Struggle for Islam, Department of Anthropology, Boston University

$\begin{array}{ccc}{ }^{17} \text { Karin Zeitvoge, Western View on Islam after September 11, artikel online bisa } \\ \text { diunduh } & \text { di } & \text { website: }\end{array}$ com/news/index.php?mod $=$ article $\&$ cat $=$ World $\&$ article $=732$ h. 2 .

${ }^{18}$ Islam Online, Report: After 9/11 Muslims Witnessed The Good, Bad \& Ugly,

${ }^{19}$ Ibid.

${ }^{20}$ Hal yang sama dialami oleh kaum Muslim di Inggris, Perancis, Jerman dan negara-negara Eropa lainnya.

TEOLOGIA, VOLUME 23, NOMOR 2, Juli-DeSEMBER 2012 
${ }^{21}$ Moeflich Hasbullah, "Islam di Amerika: Sebuah Keajaiban Bernama 9/11', Pikiran Rakyat, 6 Maret 2008

22 NewsVoaCom, Umat Islam di Amerika Setelah Serangan Teroris 11 September, 05/10/2001, hlm. 1, artikel online: http://www.voanews.com/indonesian/archive/2001-10/a-2001-10-05-5-

1.cfm?renderforprint $=1$ \&pageid $=73725$

${ }^{23}$ Ibid..

${ }^{24}$ Anies Baswedan, “Catatan Reflektif Pasca 11 September 2001," Permias, 3 Oktober 2001.

${ }^{25}$ Ibid.

${ }^{26}$ Apter, David E., 1998, The Legitimization of Violence, New York University Press, New York, h.12

${ }^{27}$ Schorlemer, Sabine von, 2003, Human Rights : Substantive and Institutional Implications of the War against Terrorism, EJIL ( 14), h. 266.

${ }^{28}$ Evelin Gerda Lindner, 2001), "Women and Terrorism: The Lesson of Humiliation", New Routes: A Journal for Peace Research and Action. Special Issue: Targetting Women, 6 (3), h. 5

${ }^{29}$ Ibid.

${ }^{30}$ Abu Bakar Ba'asyir, transkrip diskusi bersama Diskusi Ulil Abshar-Abdalla dan Abu Bakar Ba'asyir dl.

${ }^{31}$ Ismail, Noor Huda, "Mengurai Teror Bom di Indonesia," makalah Seminar 'Saatnya Yang Muda Bicara", dalam rangka Dies Natalis IAIN Walisongo, Fakultas Ushuluddin IAIN Walisongo, Maret 2010.

${ }^{32}$ Daniel Pipes, A New Round of Anger and Humiliation: Islam After 9/11, Our Brave New World, 2002, hlm. 1, artikel online: http://www. danielpipes.org/417/a-newround-of-anger-and humiliation-islam-after-9-11.

${ }^{33}$ Chicago Tribune, 30 September 2001.

${ }^{34}$ Anies Baswedan, "Catatan Reflektif Pasca 11 September 2001," Permias, 3 Oktober 2001, h. 1.

${ }^{35}$ Robert W. Hefner, September 11 and the Struggle for Islam, Department of Anthropology, Boston University.

${ }^{36}$ Akbar S. Ahmed menyatakan, "I don't look at what is coherent, strong and historical, which is the idea of the clash of civilizations, and simply say it doesn't exist, because that would not only be inaccurate and untrue, but it would not be cognitive. We have to take an idea and grapple with it, understand it, engage with it. The clash exists because it has existed for a thousand years, exactly as Huntington has stated. We have had the centuries of the Crusades and then of European colonization spanning over a thousand years of history, which has made for a complex and difficult relationship between Islam and the West. But we have also had - this is my criticism of Huntington, 
because he leaves it out -- great periods of harmony, cultural synthesis and interaction of ideas. For example, the entire corpus of Greek thinking of the great philosophers such as Aristotle and Plato, lay unknown and forgotten until the Muslims translated them in Muslim Spain a thousand years ago and allowed Europeans to discover them in Arabic, translate them into Latin and from Latin they were translated into French and then English. Over the centuries, the process of rediscovering the Greeks came to Europe via the Muslims. This cycle, in turn, triggered the European Renaissance and the Enlightenment. When you talk about Jeffersonian ideals of the Enlightenment and Jefferson's Greek heroes, we invariably omit the Muslim contribution to this cycle." Lih.t: Pew Forum on Religion \& Public Life, Five Years After 9/11, 'Dialogue' with Islam Cause for Hope, Tuesday, August 22, 2006, Bethesda, Maryland, artikel online: http://pewforum.org/events/?EventID=124.

${ }^{37}$ Noor Huda Ismail, “Mengurai Teror Bom...”, h. 5.

${ }^{38}$ Ibid.

${ }^{39}$ Ekaterina Stepanova, Terrorism.

${ }^{40}$ Noor Huda Ismail, “Mengurai Teror Bom...”, h. 5.

${ }^{42}$ Ibid, h. 6.

${ }^{43}$ Karin Zeitvoge, "Western View on Islam after September 11," artikel online bisa diunduh di website: http://www.arabamericannews.com/news/ index.php? $\mathrm{mod}=$ article $\&$ cat $=$ World $\&$ article $=732$

${ }^{44}$ Ibid.

\section{DAFTAR PUSTAKA}

Anshari, Fauzan, dalam diskusi bersama Ulil Abshar-Abdalla, dll, "Bom di Bali, Islam dan terorisme", disiarkan Radio 68H (Jakarta) dan jaringannya pada tanggal 22 November 2002. Available Online: (http://media.isnet.org/islam/Etc/BomBali.html).

Apter, David E., The Legitimization of Violence, New York: New York University Press, 1998.

Ba'asyir, Abu Bakar, transkrip diskusi bersama Diskusi Ulil AbsharAbdalla dan Abu Bakar Ba'asyir dll, "Bom di Bali, Islam dan terorisme", disiarkan Radio 68H (Jakarta) dan jaringannya pada tanggal 22 November 2002. Artikel online: (http://media.isnet.org/islam/Etc/BomBali.html). 
Baswedan, Anies, Catatan Reflektif Pasca 11 September 2001, Permias, 3 Oktober 2001.

Campbell, David, Dad what's a terrorist? Available online: http://www.theage.com.au/articles/2004/04/22/1082616260498.ht $\mathrm{ml}$

Canada and the World Backgrounder, The fourth wave: religion, albeit grossly disorted, is a common characteristic among most of the international terrorist groups that are active today, Waterloo, vol. 67, Iss. 4 (2002), available online: http://gateway.proquest.com/

Esposito, John L., Ancaman Islam: Mitos atau Realitas?, Bandung: Mizan, 1994.

Garry Blunt, Studying Islam after September 11: Reflections and Resources, the University of Wales, Lampeter, artikel online: http://www.islamfortoday.com/bunt01.htm

Haliday, Fred, 2004, Terrorism in historical perspective, (online) available: http://www.opendemocracy.net/articles/ViewPop UpArticle.jsp?id=2\&articleId $=1865$

Halliday, Fred, The Crisis of Universalism: America and Radical Islam After 9/11, Open Democracy, 2004, artikel online: http://www.opendemocracy.net

Hasbullah, Moeflich, Islam di Amerika: Sebuah Keajaiban Bernama 9/11, Pikiran Rakyat, 6 Maret 2008

Islam Online, Report: After 9/11 Muslims Witnessed The Good, Bad \& Ugly, artikel online: http://www.islamonline.net/English/ News/2002-09/07/article20.shtml

Ismail, Noor Huda, "Mengurai Teror Bom di Indonesia," makalah Seminar 'Saatnya Yang Muda Bicara", dalam rangka Dies Natalis IAIN Walisongo, Fakultas Ushuluddin IAIN Walisongo, Maret 2010.

Kelsay, John, 2002, 'Suicide bombers: the just war' debate, Islamic style', The Christian Century, August 14, vo1. 19 il7 (2002), (online) Available: Flinders University Library Expanded Academic ASAP Plus.

Kimura, Ehito, Indonesia and Islam: Before and After 9/11, Peace Work, December 2001/January 2002, artikel online: http://www.peaceworkmagazine.org/pwork/0112/011216.htm 
Lindner, Evelin Gerda, 2001, "Women and Terrorism: The Lesson of Humiliation", New Routes: A Journal for Peace Research and Action. Special Issue: Targetting Women, 6 (3).

NewsVoaCom, Umat Islam di Amerika Setelah Serangan Teroris 11 September, 05/10/2001, artikel online: http://www.voanews.com/indonesian/archive/2001-10/a-2001-1005-5-1.cfm?renderforprint $=1$ \&pageid $=73725$

Pew Forum on Religion \& Public Life, Five Years After 9/11, 'Dialogue' with Islam Cause for Hope, Tuesday, August 22, 2006, Bethesda, Maryland, artikel online: http://pewforum.org/events/?EventID=124

Pipes, Daniel, A New Round of Anger and Humiliation: Islam After 9/11, Our Brave New World, 2002, hlm. 1, artikel online: http://www.danielpipes.org/417/a-new-round-of-anger-and humiliation-islam-after-9-11

Robert W. Hefner, September 11 and the Struggle for Islam, Department of Anthropology, Boston University.

Schorlemer, Sabine von, 2003, Human Rights: Substantive and Institutional Implications of the War against Terrorism, EJIL (14), pp. 265-282

Stepanova, Ekaterina, Terrorism in Asymmetrical Conflict Ideological and Structural Aspect, SIPRI Research Report No. 23 (2008), Oxford University Press.

Townshend, Charles, Terrorism, $A$ Very Short Introduction, New York: Oxford University Press, 2002.

Zeitvoge, Karin, Western View on Islam after September 11, artikel online bisa diunduh di website: http://www.arabamericannews.com/news/index.php?mod=article $\&$ cat $=$ World $\&$ article $=732$ 